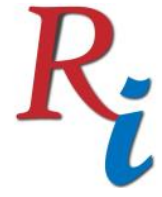

Asia Proceedings of Social Sciences

(APSS)

www.readersinsight.net/APSS

\title{
DIVERSITY IN HIGHER EDUCATION: DOES INSTITUTIONAL DIFFERENTIATION EXIST IN THE NIGERIAN HIGHER EDUCATION SYSTEM?
}

\section{Muftahu Jibirin Salihu}

National Higher Education Research Institute (NaHERI)

Universiti Sains Malaysia

Malaysia

muftahu@usm.my

*Corrosponding author's Email: $\underline{\text { muftahu@ usm.my }}$

Peer-review under responsibility of 4th Asia International Multidisciplinary Conference 2020 Scientific Committee http://connectingasia.org/scientific-committee/ (C) 2020 Published by Readers Insight Publisher, Office \# 6, First Floor, A \& K Plaza, Near D Watson, F-10 Markaz, Islamabad. Pakistan, editor@readersinsight.net

This is an open access article under the CC BY-NC-ND license (http://creativecommons.org/licenses/by-nc-nd/4.0/). 


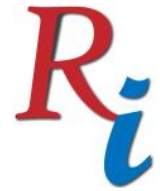

\section{Asia Proceedings of Social Sciences \\ (APSS) \\ www.readersinsight.net/APSS}

\section{A b s t r a c t}

Diversity and differentiation in higher education system are not new terms but are still relevant in the contemporary higher education debates and discourse. Different countries have different kinds of institutional differentiation in their higher education that are relevant to their context and system. For example, some countries have intensive universities, comprehensive universities, and entrepreneurial universities, which were established on different philosophies, purposes, and missions on either research discoveries, knowledge production, industrial needs, or community services; all driven by their national development policies and plans. This paper intends to explore the concept, forms, challenges, and issues of institutional differentiation in higher education system with a specific focus on universities and examine how this exists in the Nigerian higher education ecosystem in the face of diversity and sustainability in higher education. This review is aimed at understanding how such differentiation exists in terms of policy and practice in the context of the study, and how such differentiation contributes to the national development. Similarly, the paper reviewed other contexts where such institutional differentiation was placed and greatly contributed to their nation development and drew some lessons from other countries to the context of the study.

Keywords: Diversity, Higher Education, Institutional Differentiation, Nigeria.

\section{Rese a r ch H i g h I g h t s}

Establishing higher education came with numerous advantages and challenges in nearly all the educational societies in the world and this is not unconnected with the divergent objectives of different educational policymakers, economic policies, and the political influence on the education system of a country in the face of diversity in higher education. In other words, this is a way to create harmony among people of various views and backgrounds and to bridge the gaps or cement differences among members of the higher education regardless of their social, economic, political, and religious backgrounds (The College of St. Scholastica, 2016). This diversity in higher education refers to the expansion of physical structure of the institutions, broadening curriculum to capture many disciplines, and sometimes making the education system flexible to fit different needs of the students and the larger societies.

The availability of diverse higher education automatically increases the number of students' enrolment in various higher educational institutions and this translates into higher expenditure on the government's budget and a daunting task for educational authorities to expand the institutions' size, facilities, curriculum and extracurricular activities, associations, and even criteria for getting admission to these higher institutions. Many scholars have positive opinions on diversity in higher education as adding value to the educational system and it should be encouraged (Fine \& Handelsman, 2010; Sanger, 2020). Widiputera, De Witte, Groot, and van der Brink (2017) classified the diversity into systemic diversity, structural diversity, programmatic diversity, procedural diversity, reputational diversity, constituent diversity and 


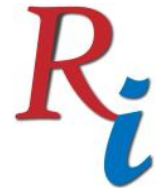

\section{Asia Proceedings of Social Sciences (APSS) \\ www.readersinsight.net/APSS}

values, and climate diversity. However, the opponents of the theory accused it as the reason behind the emergence of low-quality schools tailored to serve the low-income population. The reason for many dropouts in higher educational institutions is mostly due to financial constraints.

Differentiation becomes an integral part of educational structures and policy, which are necessary to create room for considering the circumstances causing people of different cultural, political, religious, and social backgrounds to come together under one environment for the purpose of education. In fact, Salihu (2019a) analysed the theory of organisational typologies and their application in higher education settings in which the extension discussed the institutional differentiation in higher education, and various leadership framework in higher education that may suit difference context and situations (Salihu 2019b). The nature and level of concern given to each makes differentiation apparent among many higher educational institutions in the world and Nigeria in particular. This is considered as a horizontal differentiation manifesting different sources, development, and internal dynamics of the institutions; all aiming at addressing growing concerns of providing the goal of future members of a globally competitive workforce for a sustainable development (Salihu \& Nayel, 2015). On the other hand, there is a vertical differentiation between universities, polytechnics, and other higher educational institutions in terms of the impact of education policy on education quality in the context of Nigeria (Clawson \& Page, 2011). More specifically, in terms of universities, in Nigeria there are conventional universities, Universities of Agriculture, Universities of Technology, and Universities of Petroleum Studies. There are also polytechnics, colleges of education, and other tertiary institutions.

\section{Research Objectives}

The objectives of this research are:

1. To identify the significance and benefits of diversity and differentiation in higher education, and

2. To examine the existence of diversity and differentiation in the Nigerian higher education system.

\section{Purpose of the Study}

Considering the academic outcomes of the application of diversity and differentiation in higher education in many countries especially Nigerian counterparts, this research intends to study how the application of diversity and differentiation in higher education can bring positive development in the Nigerian higher educational institutions. 


\section{Methodology}

In an educational research, there are some guiding principles that guarantee effectiveness to a certain degree in achieving the desired research objectives (Salihu, 2016). Consequently, this research adapts a review of recent and available literature on diversity and differentiation in higher education in some selected higher educational institutions in counterpart countries. The works reviewed are both in favour and against the concept, with practical examples drawn from previous research findings. Nigeria is the case study of this research and a review of both diversity and differentiation of higher education are studied and analysed.

\section{Resultsand Findings}

Diversity in higher education has been in existence since the establishment of secular education in Nigeria. However, recently, more private universities are taking the ground. This is in addition to other diverse system of higher education such as open universities, which are found in virtuously all states of the federation. In spite of the evident need for diversity in the Nigerian universities, it is apparent that some nonconventional universities aimed at ensuring diversity and differentiation have not come to stay, either due to a lack of financial support or manpower, or both. A number of such universities cannot continue as specialised universities. Paradoxically, the federal government has established more universities and is planning for more. Some recent examples from the findings of this study were the Nigerian Army University in Biu, Nigerian Maritime University, Okerenkoko, and University of Transportation in Daura in Katsina State that were established for diversity and ensured differentiation.

The standard of education, which is already in a dilapidating situation, may get even worse as these diverse universities do not have enough qualified lecturers nor sufficient laboratory equipment for research and experiments. The proliferation of commercially-oriented private institutions has been both a blessing and a curse at the same time. Private universities accommodate candidates that cannot get admission to public universities but the tuition fees are exuberantly high and the educational standard of the universities is also poor. However, there is a strong need to replenish the educational values in all higher educational institutions regardless of their vertical or horizontal diversity.

\section{REFERENCES}

Clawson, D., \& Page, M. (2011). The future of higher education. New York: Routledge.

Fine, E., \& Handelsman, J. (2010). Benefits and challenges of diversity in academic settings. Madison, WI: Women in Science \& Engineering Leadership Institute, University of Wisconsin-Madison. Retrieved from https://wiseli.wisc.edu/wpcontent/uploads/sites/662/2018/11/Benefits_Challenges.pdf 


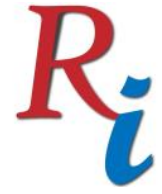

\section{Asia Proceedings of Social Sciences (APSS) \\ www.readersinsight.net/APSS}

Salihu, M. J., \& Ramadneh, N. M. A. (2015). The need for global educators? Their significance in the present time and implication for quality education. Global Journal of Educational Studies, 1(2), 67-76. https://doi.org/10.5296/gjes.v1i2.9261

Salihu, M. J. (2016). Qualitative and quantitative debates in contemporary educational research. International Journal of Research in Educational Methodology, 7(5), 1323-1327. https://doi.org/10.24297/ijrem.v7i5.4343

Salihu, M. J. (2019a). An analysis of theory of organisational typologies and their application in higher education institutional settings. Asian Research Journal of Arts \& Social Sciences, 9(4), 1-7. https://doi.org/10.9734/arjass/2019/v9i430149

Salihu, M J., (2019b). A Conceptual Analysis of the leadership Theories and Proposed Leadership Framework in Higher Education. Asian Journal of Education and Social Studies, 5(4): 1-6, 2019. pp 1-7. https://doi.org/10.9734/ajess/2019/v5i430164

Sanger, C. S. (2020, January 7). Diversity, inclusion, and context in Asian higher education. In C. S. Sanger, \& N. W. Gleason (Eds.), Diversity and inclusion in global higher education: Lessons from across Asia (pp. 1-28). Singapore: Palgrave Macmillan.

The College of St. Scholastica. (2016, August 29). What does 'diversity in college' actually mean? Retrieved May 2, 2020, from http://www.css.edu/the-sentinel-blog/whatdoes-diversity-in-college-actually-mean.html

Widiputera, F., De Witte, K., Groot, W., \& van der Brink, H. M. (2017). Measuring diversity in higher education institutions: A review of literature and empirical approaches. IAFOR Journal of Education, 5(1), 47-63. https://doi.org/10.22492/ije.5.1.03 